\title{
O princípio pluralista diante das dimensões do lúdico e da festividade
}

\author{
The pluralist principle in relation to the dimensions \\ of ludic and festivity \\ Claudio de Oliveira Ribeiro ${ }^{a}$
}

\section{Resumo}

A pesquisa tem como foco destacar aspectos de novas linguagens teológicas, forjadas nas expressões dos desejos humanos e associadas às dimensões lúdicas e místicas de formas de vida marcadas pela festividade, pela alteridade, pela afirmação da diferença, pela poesia e pelo empoderamento de grupos subalternizados que, nos entrelugares de suas culturas, revelam visões plurais e criativas de vida. Entre os resultados alcançados na pesquisa, destacamos o valor das teologias narrativas e da teopoética, que representam visões de recriação da linguagem teológica, com elementos simbólicos e de forte apelo existencial que traduzem concepções teológicas fundamentais da fé. Metodologicamente, procuramos seguir na trilha de pensar a vida e as experiências religiosas a partir do lugar criativo e propositivo dos entrelugares e fronteiras das culturas, assim como estar atentos à perspectiva dos estudos culturais decoloniais que destaca a tríplice demanda de decoloniadade do poder, do saber e do ser. Para isso, nos esforçamos em articular o princípio pluralista com visões antropológicas que valorizam o lúdico e a festividade, uma vez que tais dimensões nem sempre são realçadas nas análises teológicas e constituem intensa força mobilizadora da vida.

Palavras-chave: Princípio pluralista. Lúdico. Festividade. Método teológico. Teologia da Libertação.

\section{Abstract}

The research focuses on aspects of new theological languages, forged in the expressions of human desires and associated with the playful and mystical dimensions of life forms

\footnotetext{
a Universidade Federal de Juiz de Fora (UFJF), Juiz de Fora, MG, Brasil. Doutor em Teologia, e-mail: cdeoliveiraribeiro@gmail.com
} 
marked by festivity, alterity, affirmation of difference, poetry and the empowerment of groups and people subalternized people who, in the interweaves of their cultures, reveal plural and creative visions of life. Among the results achieved in the research, we highlight the value of narrative and theopoetic theologies, which represent visions of the re-creation of theological language, with symbolic elements and strong existential appeal that translate fundamental theological conceptions of faith. Methodologically, we try to follow the path of thinking about life and religious experiences from the creative and propositional place of the intertwining and borders of cultures, as well as being attentive to the perspective of decolonial cultural studies that highlights the triple demand for decolonization of power, of knowledge and of being. For this, we strive to articulate the pluralistic principle with anthropological visions that value the playful and festive, since such dimensions are not always highlighted in theological analyzes and constitute an intense mobilizing force of life.

Keywords: Pluralist principle. Playfulness. Festivity. Theological method. Liberation Theology.

\section{Introdução}

Nas pesquisas sobre a elucidação do princípio pluralista, temos percorrido uma longa e complexa trajetória que passa pelo debate em torno do pluralismo metodológico no contexto da teologia latino-americana, centrase nas questões relativas ao pluralismo religioso e culmina com dimensões do pluralismo de caráter antropológico, ampliando, assim, nosso foco de análise. No campo antropológico, consideramos ser necessário, entre outros aspectos, o aprofundamento de reflexões sobre a dimensão lúdica e da festividade, que marcam a vida humana e, de maneira especial, a pluralidade das experiências religiosas, uma vez que as reflexões teológicas têm sido majoritariamente conceituais e sistemáticas e quase sempre desprezam o valor das experiências lúdicas e de festividade em suas avaliações.

Nesta análise, realçaremos como o princípio pluralista está presente em perspectivas teológicas críticas, sobretudo aquelas que prezam pela reflexão de dimensões da subjetividade humana, sem tanta visibilidade no debate teológico, e pela valorização da pluralidade das experiências, boa parte delas vividas nos entrelugares das culturas que incidem no cotidiano das pessoas, e pela visão crítica que tais vivências podem forjar, mesmo que não pelo viés linear e racionalista. Ao mesmo tempo, consideramos que o princípio pluralista é devedor destas visões teológicas críticas e criativas que analisaremos a 
seguir, e pode ser, ainda que modestamente, um elemento de aprofundamento de tais perspectivas. Tal interação segue na perspectiva das proposições conceituais dos estudos culturais decoloniais em realçar, de forma ampla, a decolonialidade do poder, do saber e do ser (MIGNOLO, 2007).

Nossa insistência em articular o princípio pluralista com análises sobre dimensões antropológicas - e não somente sobre o pluralismo religioso —, se fundamenta na necessidade de se responder à tríplice demanda em torno da decolonialidade acima indicada. Para isso, nos esforçaremos em articular o princípio pluralista com visões antropológicas como o valor do lúdico e da festividade, uma vez que tais dimensões, como já referido, nem sempre são devidamente realçadas nas análises teológicas.

\section{O que é o princípio pluralista}

As pesquisas que procuram formular o princípio pluralista têm sido desenvolvidas no contexto dos desafios de revisão metodológica da Teologia Latino-Americana da Libertação. Não obstante a muitas e diversificadas análises, reconhecemos que não é tarefa simples indicar tais desafios ${ }^{1}$. Há, no entanto, três aspectos que têm mobilizado a atenção de teólogos e de teólogas. O primeiro é a tarefa de alargamento metodológico e de atualização nas formas de compreensão da realidade, como se espera das teologias de natureza social e política. No caso latino-americano, trata-se de avaliar o peso dos esquemas reducionistas que utilizaram em demasia a bipolaridade "dominantes x dominados" devido à influência de certas formas de marxismo nas análises sociais, ocultando por vezes a complexidade social. Para isso, as teorias e lógicas de complexidade ${ }^{2}$, são fundamentais para o reforço de perspectivas plurais para o conhecimento e análise da realidade.

\footnotetext{
${ }^{1}$ A lista de autores e autores e a bibliografia a respeito da Teologia da Libertação é amplíssima. Para uma visão de conjunto veja, entre tantas outras obras, o recorte que fizemos das mais recentes entre docentes de Programas de Pós-Graduação da Área: Teologia Latino-Americana: raízes e ramos, de Maria Clara Bingemer (2017), Teoria teológica \& Práxis teologal: sobre o método da Teologia da Libertação, de Francisco de Aquino Júnior (2012) e Testemunho e Libertação: a Teologia Latino-Americana em Questão, de Claudio Ribeiro (2016).

${ }^{2}$ Aqui, como já indicado em A dimensão política da Teologia Protestante da Libertação (2018), nos apoiamos na teoria da complexidade, de Edgar Morin, no que afirma ser o pensamento complexo essencialmente aquele "que trata com a incerteza e que é capaz de conceber a organização. É o pensamento capaz de reunir (complexus. aquilo que é tecido conjuntivamente),
} 
Um segundo desafio está em torno das questões relativas à emergência das subjetividades na atualidade. Esta dimensão se conecta com a espiritualidade. Não foram poucas as vezes em que a Teologia da Libertação foi acusada de não ter espiritualidade. As características racionais do método teológico latino-americano, como as mediações socioanalíticas para a compreensão científica da realidade, o rigor hermenêutico nas exegeses bíblicas e nas avaliações históricas e as formas articuladas e programadas de ação eclesial e política marcam uma racionalidade que talvez possam, de fato, inibir formas mais subjetivas de espiritualidade. No entanto, a mística evangélica é parte constitutiva da participação cristã nos processos de libertação social. Daí a emergência de grandes desafios teológicos e pastorais, em geral requerendo uma abertura a visões que valorizem a subjetividade e formas mais autênticas de espiritualidade.

Um terceiro desafio reside em torno dos encontros e desencontros da teologia com a pluralidade. A Teologia da Libertação priorizou os aspectos políticos para suas interpretações e nem sempre esteve atenta às diferenças culturais, que, no caso do continente latino-americano, são fortemente híbridas e entrelaçadas com a diversidade das expressões religiosas. Também pouco esteve atenta às demandas da vida que surgem com as dimensões do cotidiano e com os aspectos fundamentais da vida humana, como a corporeidade e a sexualidade. Portanto, está diante da teologia latinoamericana a tarefa de aprofundar os seus esforços, mesmo com as suas limitações e ambiguidades, e, guiada pelo princípio pluralista, refletir sobre as demandas que a sociedade apresenta e que recaem sobre o quadro de pluralismo, seja o que está em torno das questões do método teológico, do quadro religioso ou de questões de natureza antropológica. Estas últimas

de contextualizar, de globalizar, mas, ao mesmo tempo, capaz de reconhecer o singular, 0 individual, o concreto" (MORIN; MOIGNE, 2000, p. 207). "O pensamento complexo busca questionar e expandir de maneira crítica os pensamentos simplificadores, partindo da não completude do conhecimento e da aceitação da diversidade dos saberes e percepções acerca do mundo e da vida. A realidade é vista como um tecido de múltiplos fios interligados e em permanente processo de construção e reconstrução. O pensamento complexo critica os três pilares da ciência moderna, sem, contudo, negar a eficácia deles: a ordem, a separabilidade e as lógicas indutiva e dedutiva (MORIN, 2008). Como para o autor tudo está em intrínseca relação, assim, teríamos a relativização das concepções simplificadoras, dando lugar a concepções complexas e pluridimensionais da realidade. 
podem ser exemplificadas na capacidade de alteridade ecumênica, nas formas autênticas de espiritualidades integradoras, inclusivas e ecológicas, e no valor da corporeidade, da sexualidade e da dimensão lúdica na reflexão teológica e nas ações concretas de afirmação da vida (RIBEIRO, 2016).

O princípio pluralista tem sido compreendido como um instrumento hermenêutico de mediação teológica e analítica da realidade sociocultural e religiosa que procura dar visibilidade a experiências, grupos e posicionamentos que são gerados nos "entrelugares", bordas e fronteiras das culturas e das esferas de institucionalidades. Como indicado em textos anteriores, o princípio pluralista possibilita divergências e convergências novas, outros pontos de vistas, perspectivas críticas e autocríticas para diálogo, empoderamento de grupos e de visões subalternas e formas de alteridade e de inclusão, considerados e explicitados os diferenciais de poder presentes na sociedade (RIBEIRO, 2017a, 2017b, 2020).

O princípio pluralista tem sido formulado a partir de visões teológicas ecumênicas e do conceito filosófico e antropológico de alteridade. Ele possibilita melhor compreensão da diversidade do quadro religioso e também das ações humanas. Não se trata apenas de uma indicação ética ou “catequética”. Com o princípio pluralista, as análises sociais tornam-se mais consistentes e completas, uma vez que possibilitam uma identificação mais adequada e detalhada do "outro". Este não é mais visto de forma idealizada, mas concretamente identificado, especialmente as pessoas e grupos que são invisibilizados dentro da visão sociológica que Boaventura de Souza Santos (2010) denominou "sociologia das ausências". A sensibilidade com as distintas expressões culturais ou religiosas, sobretudo as minoritárias e fronteiriças, contribui para uma "sociologia das emergências"3 de novos rostos, variados

\footnotetext{
3 "Trata-se de uma investigação que visa demonstrar que o que não existe é, na verdade, activamente produzido como não existente, isto é, como uma alternativa não-credível ao que existe" (SANTOS, 2010, p. 102). A realidade não pode ser reduzida ao que existe. Para dar visibilidade às realidades ativamente produzidas como não existentes é necessário se criar uma visão ampla de realismo, o que o autor chama de ecologias. Nelas estão presentes: (i) a ecologia dos saberes, que articula criticamente os saberes científicos e os considerados não científicos, (ii) a ecologia das temporalidades, que integra diferentes concepções de mundo, de tempo e organização da vida cotidiana, (iii) a ecologia dos reconhecimentos, que valoriza diferentes grupos sociais e suas identidades e visões de resistência social e luta política nos processos de emancipação, (iv) a ecologia das trans-escalas, que destaca a recuperação de aspirações universais alternativas de justiça social, dignidade, respeito mútuo, solidariedade, comunidade e
} 
perfis religiosos, multiplicidades de perspectivas, olhares e formas plurais de atuação na sociedade e no cotidiano. Com essa perspectiva "policromática" os esforços de análise do presente ou os de identificar os futuros das religiões poderiam encontrar maior êxito.

Seguimos a concepção de entrelugar, como trabalho fronteiriço da cultura, conforme nos indica Homi Bhabha em sua obra O local da cultura (2001), que requer um encontro com "o novo" que não seja mera reprodução ou continuidade de passado e presente. Para as nossas reflexões, especialmente no que comumente nos referimos à necessidade de alargamento de horizontes metodológicos para o estudo da religião, consideramos que o "local da cultura" [para usar o sugestivo título da obra] é fundamental no processo que advogamos de estabelecer mediações socioanalíticas para as interpretações teológicas e, também, para as análises científicas da religião em geral. O conceito entrelugar está relacionado à visão e ao modo como grupos subalternos se posicionam frente ao poder e como realizam estratégias de empoderamento. Tais posicionamentos geram entrelugares, especialmente experimentados nas malhas do cotidiano, em que aparecem com maior nitidez questões de âmbito comunitário, social e político. A visão de fronteira possibilita uma visibilidade mais nítida das estruturas de poder e de saber, o que pode ajudar na apreensão das subjetividades de povos subalternos e de grupos sociais invisibilizados pelas estruturas de poder.

Com as visões acerca da noção de entrelugares e de fronteiras, constituídas com base nas concepções de Homi Bhabha e Boaventura de Souza Santos, reforçamos a perspectiva dos estudos culturais, que em solo latino-americano ganhou, a partir dos estudos, sobretudo do peruano Anibal Quijano, da estadunidense radicada no Equador Catherine Walsh, e dos argentinos Enrique Dusssel e Walter Mignollo, um novo conteúdo crítico. Trata-se da perspectiva ou giro decolonial, o qual possui um sentido estratégico que revela interpelações políticas e epistemológicas de

espiritualidade, harmonia natureza e sociedade, e de outras formas de escalas locais/globais que não resultam da globalização hegemônica, (v) a ecologia das produtividades, que amplia a realidade social por intermédio de experiências econômicas alternativas e realistas para a construção de uma sociedade mais justa. Daí, a noção de diferença cultural se reforça na medida em que inclui as realidades ausentes seja por silenciamento, supressão ou marginalização (SANTOS, 2010). 
reconstrução de culturas, instituições e relações sociais, tendo em perspectiva o empoderamento de grupos subalternos e construções críticas alternativas e plurais. As proposições conceituais dos estudos culturais decoloniais visam realçar a decolonialidade do poder, do saber e do ser (MIGNOLO, 2008). Com isso, as aproximações religiosas e a valorização do pluralismo podem ser, não somente percebidas e terem suas tendências identificadas nas análises, mas, elas podem ser, sobretudo, construídas. É obvio que isto se trata de tarefa dos próprios grupos religiosos e da interação deles na sociedade, mas os estudos de religião podem cooperar oferecendo análises cujas bases sejam sólidas e ao mesmo tempo criativas e indicadoras de novos caminhos. Nossa intenção em articular o princípio pluralista com análises sobre o pluralismo metodológico, religioso e antropológico - se fundamenta, entre outros aspectos, na necessidade de se responder à referida tríplice demanda em torno da decolonialidade.

A formulação do princípio pluralista se deu em variados ambientes acadêmicos, mas encontrou solo fértil no Grupo de Trabalho "Espiritualidades contemporâneas, pluralidade religiosa e diálogo", liderado pelos professores Gilbráz Aragão (UNICAP), Roberlei Panasiewicz (PUC Minas) e Claudio Ribeiro (PUC Campinas). Em linhas gerais, o GT se orienta da seguinte forma:

Diante do contexto culturalmente plural em que nos encontramos e que desafia as
tradições religiosas, acreditamos estar frente a uma grande oportunidade para o
diálogo entre as diversas religiões. Sem renegar ou desconhecer o que há de único
e irrevogável em cada religião, trata-se de perceber, no convívio com a diversidade,
o que é essencial em cada tradição e, portanto, de manifestar um dinamismo
espiritual que está entre e para além das religiões. Incluem-se nessa espiritualidade
aquelas expressões laicas e sem deus e o diálogo inter-religioso que elas todas
proporcionam faz repensar o compromisso ético das religiões para com a paz
mundial. O GT está aberto ao debate de pesquisas sobre a aplicação da
espiritualidade no cotidiano; aos estágios do desenvolvimento da experiência
espiritual e a função da meditação, bem como sobre os desvios do comportamento
supersticioso e do misticismo. Estuda a pluralidade religiosa atual e tendências de
diálogo na contemporaneidade. Esperamos, com tais discussões, propor respostas
para aqueles que negam qualquer validade da religião na sociedade contemporânea
e, talvez, o caminho para uma nova compreensão da religiosidade, que se
contraponha ao flagrante fundamentalismo religioso de nossos dias. Pretendemos
subsidiar, teoricamente, as práticas de diálogo inter-religioso que vêm sendo
ensaiadas com apoio dos Programas de Ciências da Religião e Teologia no Brasil, no 
sentido de verificar a plausibilidade de uma mística comum e transreligiosa para o nosso tempo de transformações axiais ${ }^{4}$.

Nossas reflexões fazem um percurso que vai da dimensão transdisciplinar à perspectiva transreligiosa. A formulação do princípio pluralista bebeu das fontes deste caminho.

A transdisciplinaridade engrendra, pois, uma atitude trans-cultural e trans-religiosa. A atitude trans-cultural designa a abertura de todas as culturas para aquilo que as atravessa e ultrapassa, indicando que nenhuma cultura se constitui em um lugar privilegiado a partir do qual podemos julgar universalmente as outras culturas, como nenhuma religião pode ser a única verdadeira e universal (ARAGÃO, 2008, p. 142143).

O princípio pluralista, portanto, arquitetado sob a noção de entrelugares da cultura e estabelecido também sob outras duas grandezas - alteridade e ecumenicidade - pode reforçar as experiências religiosas e culturais que se constituem como aprofundamento dos processos de humanização, da democracia, da cidadania, e da capacidade contra-hegemônica na defesa de direitos humanos e da terra. O mesmo é possível afirmar em relação à necessidade de tais experiências serem vistas e analisadas, se considerando as relações assimétricas de poder presentes na sociedade e as formas de colonialidade. Em ambos os casos, alteridade e visão ecumênica são chaves significativas de interpretação do quadro de pluralismo religioso.

\section{Princípio pluralista, teologia narrativa e teopoética}

Na pesquisa mais geral que desenvolvemos, cujos resultados têm sido apresentados em variados artigos e livros, temos procurado aplicar o princípio pluralista a diferentes situações e contextos, procurando dialogar com os estudos culturais decoloniais. Para essa análise que ora realizamos sobre as dimensões do lúdico e da festividade, seguimos com outra base teórica, sem relação direta e explícita com o decolonialismo, mas mantendo um "espírito"

\footnotetext{
${ }^{4}$ GT "Espiritualidades contemporâneas, pluralidade religiosa e diálogo", vinculado à Soter (Sociedade de Teologia e Ciências da Religião) e à Anptecre (Associação Nacional de Pesquisa e Pós-Graduação em Teologia e Ciências da Religião) que envolve em sua articulação três Programas de Ciências da Religião de universidades confessionais. Ementa do grupo. Disponível em: http://www.unicap.br/observatorio2/?p=2586. Acesso em: 14 maio 2019.
} 
crítico peculiar. Trata-se da crítica teológica feita por Rubem Alves ao racionalismo presente em setores da teologia latino-americana. Tal perspectiva tem sido cada vez mais valorizada nos estudos de religião ${ }^{5}$ e, ainda que sem relação direta com a visão decolonial, representa um referencial crítico de fundamental importância para o princípio pluralista, uma vez que se trata de uma visão propositiva no tocante à superação de formalismos, dogmatismos e lógicas de pensamento único.

Rubem Alves enfatizou a crítica ao racionalismo e ao pragmatismo presentes no pensamento teológico ao recorrer à teologia narrativa e à teopoética. Com Variações sobre a Vida e a Morte: a teologia e sua fala (1982b), por exemplo, ele mostrou outras possibilidades de caminhos e linguagens teológicos. Isso ele já o fizera com obras escritas originalmente em inglês como a sua tese Toward to a Liberation Theology (Por uma Teologia da Libertação), publicada como Theology for Human Hope (Teologia da Esperança Humana), mas que quase ninguém conhecia em terras brasileiras (RIBEIRO, 2019).

Com Variações, Rubem Alves revela outra etapa de seu pensamento. $\mathrm{Na}$ virada para os anos de 1980 há uma mudança significativa no pensamento do autor. Este teólogo buscou uma nova linguagem que pudesse responder mais adequadamente às demandas que surgiam com a emergência das subjetivas humanas que se afloravam no mundo. Tendo em vista as análises sobre o princípio pluralista para o método teológico e científico, pode-se dizer que Rubem Alves "rasgou o verbo". Ele recriou a linguagem, com novas perspectivas interpretativas, valorizou as reticências, os vazios, a incompletude. Daí o destaque que damos a ele em nossas interpretações teológicas de cunho antropológico.

Rubem Alves ressaltou o caráter lúdico de seu pensamento ao utilizar a narrativa associada ao famoso “jogo das contas de vidro", da obra de Hermann Hesse. Para Alves, a teologia é vista como brinquedo, que transfigura o mundo, nos faz pensar livremente, questionando os velhos preceitos e dogmas e nos

\footnotetext{
${ }^{5}$ Exemplos disto são as numerosas produções acadêmicas nos últimos anos em torno do pensamento de Rubem Alves. Uma visão geral pode ser encontrada no Dossiê "A poética da religião em Rubem Alves", organizado por Paulo Augusto de Souza Nogueira, em Estudos de Religião, v. 31, n. 2, maio-ago. 2017, e o livro Rubem Alves e as contas de vidro, organizado por Breno Martins Campos, Ceci Baptista Mariani e Claudio de Oliveira Ribeiro (2020).
} 
fazer ver e recriar a vida em sua multiplicidade de situações, em especial as dinâmicas relativas à corporeidade.

Porque a conta de vidro temática é o corpo humano, meu corpo, corpo de todos os homens, corpo de jovens e de velhos, corpos torturados e corpos felizes, corpos mortos e corpos ressuscitados, corpos que matam e corpos abraçados em amor. E a congregação de teólogos e assistentes repete, em uníssono: "Creio na ressurreição do corpo" (ALVES, 1982b, p. 31).

O autor realça três dimensões significativas para a fé como a imaginação, a criatividade e o espírito de aventura. Tais dimensões estão para além dos limites religiosos que tornam o humano refém de dogmatismos e também para além das certezas que não os deixam arriscar nas mais diferentes realidades e possibilidades da vida.

Aí imaginação emigra da realidade, aliena-se, torna-se estranha ao mundo, recusa o veredito dos fatos, e começa a explorar possibilidades ausentes, a montar fantasias sobre o jardim que poderia existir, se 0 amor e 0 trabalho transformassem a realidade. A imaginação voa e o corpo cria.

A imaginação são as asas do corpo.

O corpo, a força da imaginação.

O desejo e o poder se interpenetram para dar à luz a esperança (ALVES, 1982b, p. 45).

Em Lições de feitiçaria: meditações sobre a poesia (2003, p. 55), Rubem Alves realça que...

"Antes que todas as coisas existissem

havia o silêncio.

E então, repentinamente, ex nihilo

uma Palavra foi ouvida, e o mundo começou..."

No vazio, versos, universos,

[...] e eles falaram como poetas, como mágicos, como amantes, como teólogos,

porque teologia é a Palavra falada diante do vazio, como uma invocação do Ausente... 
A teopoética de Rubem Alves foi bastante popularizada com a publicação de Creio na ressurreição do corpo (1982c). Nela encontramos "pérolas" escatológicas como esta:

Salvação! Nossos corpos totalmente livres.

Livres de tudo o que faz sofrer.

Livres das correntes, do medo. Os olhos não mais perfurarão, e nenhum irmão terá de esconder, do seu irmão, nem a nudez da sua alma e nem a nudez do seu corpo. Livres para a verdade, livres para a beleza, livres para o amor. Insólita política porque nossos corpos não mais reagirão nem ao olho mau, nem ao gesto mau, nem à palavra má. Possuídos pelo futuro trataremos de fazer viver, no presente, aquilo que nos foi dado, em esperança. E esta comunidade de visionários, de exilados, de peregrinos, de árvores desenraizadas, servirá ao mundo, na própria vida, em sacramentos do Reino de Deus que se aproxima (1982c, p. 71).

\section{Em O Enigma da Religião, o autor confessa:}

Comecei a perseguir a beleza mais que a verdade. É que descobri, tardiamente, através da surpresa de amizades inesperadas, o fascínio da poesia. Que poema será verdade? Que poema será reflexo especular fiel das coisas do nosso mundo? Poemas, invocações de ausências, funduras onde nadam os desejos: é aí que os corpos se preparam para as batalhas [...]. Visitando a mim mesmo e lendo as coisas dos mundos mágicos e dos mundos dos sonhos, aprendi que o corpo não é coisa biológica: poemas que se fizeram carne. Somos moradas de palavras, possessões demoníacas ou o vento indomável do Espírito. Palavras: continuação das mãos. Mas, forma visível das palavras. Há de se buscar a palavra que se transforma em carne: aqui, o segredo do dizer mágico. Não basta o saber; é preciso o sabor. É preciso que as palavras sejam belas, para seduzir (ALVES, 1975, p. 57).

Em O Deus que conheço, o autor afirma: "Os poetas, diferentes dos cientistas, que desejam conhecer o universo olhando diretamente para ele, só conhecem o universo como parte do seu corpo. Poesia é eucaristia. O poeta contempla a coisa e diz: 'Isso é meu corpo"' (ALVES, 2010, p. 27). E continua o autor:

Foi numa Sexta-Feira da Paixão que compreendi. Uma rádio FM estava transmitindo, o dia inteiro, músicas da tradição religiosa cristã. E eu fiquei lá, assentado, só ouvindo. De repente, uma missa de Bach, e a beleza era tão grande que fiquei possuído e chorei de felicidade: "a beleza enche os olhos d'água (Adélia Prado). Percebi que aquela beleza era parte de mim. Não poderia jamais ser arrancada do meu corpo. Durante século os teólogos, seres cerebrais, se dedicaram a transformar a beleza em discurso racional. A beleza não Ihes bastava. Queriam certezas, queriam a verdade. Mas os artistas, seres-coração, sabem que a mais alta forma de verdade é a beleza. Agora sem a menor vergonha, digo: Sou cristão porque amo a beleza que mora nessa tradição (ALVES, 2010, p. 31). 
Em Variações, Rubem Alves havia dado um rotundo "não” às pretensões de neutralidade.

Não. Não existe um mundo neutro. O mundo é uma extensão do corpo. É vida: ar, alimento, amor, sexo, brinquedo, prazer, praia, céu azul, auroras, crepúsculos, dor, mutilação, impotências, velhice, solidão, morte, lágrimas, silêncios. Não somos seres do conhecimento neutro, como queria Descartes. Somos seres do amor e do desejo. E é por isso que a minha experiência da vida é essencialmente emoção (1982b, p. 39).

Estamos realçando a perspectiva do lúdico, mas, ao mesmo tempo, afirmamos o questionamento à total evasão do mundo como felicidade. $O$ mesmo fazemos em relação à fuga das explicações mais racionais e científicas das vicissitudes da vida. Esse é um aspecto complexo que acrescenta uma série de questionamentos à prática religiosa, por sua vez já complexa. Porque, se as pessoas não podem fugir totalmente de suas realidades, por outro lado, encará-las é uma difícil tarefa, devido ao elevado grau de sofrimento e de degradação da vida humana na atualidade.

No campo popular é impressionante a precariedade na qualidade de vida das pessoas. A maioria tem a saúde mental debilitada; os problemas familiares e existenciais são diversos; a vida material é desumana: moradias minúsculas, insegurança no trabalho, pouco ou nenhum lazer. Diante disso, são necessários esforços de "consolação", mas na maioria das vezes, ao menos nos ambientes orientados pela perspectiva religiosa politizada da “libertação”, a ênfase encontra-se somente nas ações de transformação social e política. Como propor projetos/empenho/reflexões/estudos/reuniões em meio a tanto sofrimento? Será possível que um deslocamento um pouco acima da realidade possa ajudar a enfrentá-la? Ou a fé e a vivência religiosa estão confinadas a serem uma completa fuga de tudo? O autor havia indicado algo nesta direção em Dogmatismo e tolerância ao afirmar que a fé ajuda a “exorcizar o medo e construir diques contra o caos" (ALVES, 1982a, p. 24).

\section{Inoperosidade, magia e festa}

Embora com perspectivas distintas das de Rubem Alves, outro autor que contribui nas reflexões em torno do lúdico e da festividade é o renomado 
filósofo italiano Giorgio Agambem. Em linhas gerais, ele realça o valor da poesia, do jogo e do lúdico como redimensionamento da linguagem, sem atrelá-las ao mistério ou às dimensões cúlticas e religiosas. O autor questiona os processos reducionistas que esvaziam a poíesis em função da práxis. Ele opõe arte interessada e arte desinteressada, sendo essa de potencial criativo e autenticamente artístico. Tal oposição não ocorre de forma dualística, pois todo o empreendimento filosófico do autor é de fugir das formulações binárias, mas de introduzir as visões sobre a arte em uma atmosfera de ambivalência e tensão criativa (RIBEIRO, 2019).

No tocante à política, ele traça o caminho da negatividade, do "não fazer", da inoperosidade criativa, de se pensar o fazer político fora da esfera do Estado e do poder soberano que nele está amalgamado. Para ele, as estruturas da modernidade romperam a lógica da soberania divina que controlava os corpos, mas o Estado assumiu as normativas em torno da decisão sobre a vida dos indivíduos. Nesse sentido, o Estado moderno se estrutura a partir de conceitos teológicos secularizados. A soberania, por ser a prerrogativa de se decidir sobre a suspensão do ordenamento jurídico, passa a ser incorporada no Estado. Este, por sua vez, embora identificado como de direito, constitui-se como de exceção. Ele reforça os segredos ou os princípios do poder, mantendo as antigas formas de exceção soberana (RIBEIRO, 2019).

Colocando a vida biológica no centro de seus cálculos, o Estado moderno não faz mais, portanto, do que reconduzir à luz o vínculo secreto que une o poder e a vida nua, reatando assim (segundo uma tenaz correspondência entre moderno e arcaico que nos é dado verificar nos âmbitos mais diversos) com o mais imemorial dos arcana imperii (AGAMBEN, 2010, p. 14).

A potência, na inoperosidade dos atos, não está desativada. Esse aspecto é muito importante em nossas reflexões devido à dimensão propositiva do princípio pluralista, especialmente 0 caráter de empoderamento dos grupos subalternos. Para Agamben, a festividade possibilita processos de libertação dos corpos de seus movimentos utilitários e repressivos e um desvelamento de novos usos para as obras humanas, para além de dispositivos de controle. Trata-se de uma "potência destituinte", ao mesmo tempo natural e política, fruto da contemplação na qual "a obra é 
desativada e se torna inoperante, sendo assim restituída à possibilidade, aberta a um novo uso possível" (AGAMBEN, 2017, p. 277).

Considerando as noções de inoperosidade e de potência destituinte formuladas por Agamben, o lúdido, a poeisis, o riso, a ironia, o choro, as intuições, as brincadeiras, a capacidade de imaginação, a admiração extática das artes, o olhar contemplativo, os arrepios do corpo desativam poderes constituídos e relativizam formas de alternância do poder que perpetuam visões coloniais (RIBEIRO, 2019).

A proximidade entre potência destituinte e aquilo que, durante essa pesquisa, nós chamamos 'inoperosidade' se mostra aqui com toda clareza. Nos dois casos, o que está em questão é a capacidade de desativar e de tornar inoperante alguma coisa um poder, uma função, uma operação humana - sem simplesmente a destruir, mas liberando as potencialidades que estavam inativas para proporcionar um uso diferente (AGAMBEN, 2017, p. 305).

O lúdico é uma forma de contestação e de desestabilização do presente, ele sinaliza aquilo "que vem" e também a infinitude e a misericórdia divina na subversão do real. Ao apresentar o pensamento de Agamben, Selvino Assmann, sintetiza que

Profanar é assumir a vida como jogo, jogo que nos tira da esfera do sagrado, sendo uma espécie de inversão do mesmo. Convidando-nos a profanar, Agamben alerta para o fato de termos perdido a arte de viver, que é a da infância, lugar primeiro da mais séria profanação da vida, como já fora anunciado pelo Zaratustra de Nietzsche, e retomado por Benjamin, de quem Agamben não é só estudioso, mas se sente inspirado em seu 'messianismo imanente': as crianças sabem jogar e brincar, enquanto os adultos, sérios, perderam a capacidade de ser (sic) mágicos e de fazerem milagres (ASSMANN, 2007, p. 13).

Em Infância e história, o filósofo italiano argumenta que o lugar da infância está em um mundo intuitivo e simbólico, que é o próprio pensamento, "onde os nomes nos faltam, onde a palavra se parte em nossos lábios" (AGAMBEN, 2005, p. 13). Assim, segundo o filósofo, infância seria a voz humana, que não é linguagem, que não está no objeto, mas no indizível, um “não-lugar", local em que reside a experiência, mas uma experiência transcendental concebida a partir da (re)conceituação de transcendental no pensamento contemporâneo "em função de suas relações com a linguagem [...] Uma experiência que se sustém somente na linguagem, um experimentum 
linguae no sentido próprio do termo, em que aquilo de que se tem experiência é a própria língua" (AGAMBEN, 2005, p. 11). Para ele há uma queda ou destruição da experiência do ser humano contemporâneo na opressão do cotidiano, que "foi expropriado de sua experiência, aliás, a incapacidade de fazer, e de transmitir experiências talvez seja um dos poucos dados certos de que disponha sobre si mesmo" (AGAMBEN, 2005, p. 21).

Agamben mostra que o ser humano

se estabelece como sujeito de uma sociedade na, e por meio da linguagem, sendo a infância a origem da linguagem e a linguagem a origem da infância. Segundo o autor, elas estão intrinsicamente ligadas. A infância, dessa forma, coexiste originalmente com a linguagem. Ela seria o inexprimível que surge entre o signo e o discurso, é a experiência transcendental da história do ser humano que, ao contrário dos animais, ao constituir-se em sujeito da linguagem, tem capacidade de dizer-se eu (LUCKNER; KELM; RIBEIRO, 2017).

\section{Considerações finais}

Como realçado no início desta análise, as reflexões sobre o princípio pluralista têm sido efetuadas a partir do enfrentamento de, pelo menos, três desafios, interligados entre eles, que emergem da situação teológica latinoamericana: i) melhor compreensão da complexidade da realidade socioeconômica e cultural, ii) equacionamento mais adequado das relações entre racionalidade e subjetividade, e iii) os encontros e desencontros da teologia com a pluralidade, seja metodológica, religiosa ou antropológica.

Nossa intenção foi destacar aspectos de novas linguagens teológicas, forjadas nas expressões dos desejos humanos e associadas às dimensões lúdicas e místicas de formas de vida marcadas pela alteridade, pela afirmação da diferença, pela poesia e pelo empoderamento de grupos subalternizados que, nos entrelugares de suas culturas, revelam visões plurais e criativas de vida. Destacamos o valor das teologias narrativas e da teopoética, que representam visões de recriação da linguagem teológica, com elementos simbólicos e de forte apelo existencial que traduzem concepções teológicas fundamentais da fé. 
Procuramos seguir na trilha de pensar a vida e as experiências religiosas a partir do lugar criativo e propositivo dos entrelugares e fronteiras das culturas, assim como estar atentos à perspectiva dos estudos culturais decoloniais que destaca a tríplice demanda de decoloniadade do poder, do saber e do ser. Para isso, nos esforçamos em articular o princípio pluralista com visões antropológicas que valorizam o lúdico e a festividade, uma vez que tais dimensões nem sempre são realçadas nas análises teológicas e constituem intensa força mobilizadora da vida. O princípio pluralista é, ao mesmo tempo, fonte para o pensamento crítico e base de sustentação destes processos de aprofundamento teórico.

No caso das atividades religiosas há muito o que dizer. Aquelas, por exemplo, que contenham objetivos mais explícitos e que trabalhe conteúdos mais definidos (cursos, reuniões, palestras) devem estar revestidas de uma espiritualidade que preencha as expectativas religiosas das pessoas e as faça vislumbrar novos horizontes. As propostas politizadas que normalmente são apresentadas aos grupos religiosos (análises de conjuntura, debates, participação em associações, sindicatos e partidos) precisam estar presentes, pois são instrumentos da missão e da humanização do mundo e ajudam a viver. Ver racionalmente o mundo e entender suas engrenagens sociopolíticas e econômicas são aspectos fundamentais da vida e da fé. No entanto, ao mesmo tempo, a comunidade precisa ser o lugar de prazer onde ela ora, canta e cultua a Deus. Um espaço de "felicidade que não signifique a evasão do mundo, mas que, ao mesmo tempo, viva na dimensão constante da transcendência do mistério, de onde brotam os contornos de toda experiência que comece a responder aos anseios infinitos do coração" (IDÍGORAS, 1983, p. 163).

Em geral, a magia é vista com desconfiança pelas lógicas racionalistas, formais, burocráticas e institucionalistas. No entanto ela surge e se reforça em espaços inéditos e em momentos inesperados. "Nas experiências interstícias da vida, nos momentos de dor e de prazer, nas fronteiras entre frustrações e realizações, ali ela está, como potência destituinte, como convite para o riso, o choro, a dança e o gozo extático" (RIBEIRO, 2019, p. 98). Para Rubem Alves, o ser humano... 
... pratica a magia porque dentro de si possui uma intenção mágica: a de que as coisas como são têm de ser dissolvidas, e um mundo novo, expressivo do amor, deve ocupar o seu lugar. Sem a intenção mágica a cultura não teria sido criada. Pois esta nasce enquanto uma recusa humana em aceitar o mundo como ele é, e também como uma expressão de sonho utópico de se criar uma ordo amoris (ALVES, 1986, p. 91).

Inoperosidade e magia negam o transcurso das realidades. Ambas residem para além das visões escapistas, conformistas e alienantes das ilusões, e se colocam na concretude da vida e napotencialidade do novo, do inesperado, e, como usualmente Agamben se expressa: do "que virá".

A magia, de acordo com Rubem Alves, representa um ato criativo - que fora abortado pelo poder dominante. Ela é em certo nível a expressão profética de um corpo que já não aguenta mais, a manifestação de um corpo que deseja ultrapassar a ordem vigente das coisas, sem conseguir, mas que apesar disso ainda resiste. É possível afirmar que a magia - que opera no núcleo constitutivo de qualquer imaginação religiosa - é uma das performances possíveis para um corpo rebelde (CATENACI, 2018, p. 122).

Outro aspecto religioso por demais comum em função do aspecto comunitário peculiar à vivência religiosa são as festas. Elas reforçam o senso de comunidade, reforça a experiência de trabalho partilhado, e, comumente, gera alegria, comunhão e prazer, mesmo em meio à dor. Teólogos como Harvey Cox, por exemplo, que marcara o pensamento de Rubem Alves, com o seu destacado livro A Festa dos Foliões: um ensaio teológico sobre festividade e fantasia (1974), têm-nos oferecido essa contribuição. Da forma similar, a teóloga Elza Tamez, com sua produção teórica e poética, realça a dimensão divina da experiência da festa:

Quando sentimos que baixamos o céu a terra, a experiência torna-se sagrada. A experiência humana e divina se funde. Não existem fronteiras para distinguir o divino do humano. A experiência divina se faz humana e a humana, divina. Isso ocorre nas festas boas. Não existe diferença, porque Deus se faz presente no partir e compartir todo o pão. Muitas vezes os estudiosos têm rejeitado as alegorias. Porém, eu creio que as alegorias expressam também o que os textos, polissêmicos, querem dizer. 0 Cântico dos Cânticos fala de uma imensa paixão entre dois amantes, porém por que não ver também a imensa paixão de Deus pela gente e da gente por Deus, como faziam os antigos escritores cristãos? O problema acontece quando queremos ver só o aspecto divino, rejeitando o aspecto humano, ou vice-versa. Esquecemos que nas emoções intensas ultrapassamos as fronteiras ou estas se transbordam ou se desdobram (TAMEZ, 2007, p. 143-144).

\section{E autora prossegue...}


escrever desta forma não é arriscado? Será que não estamos dando as costas aos grandes desafios da América Latina e do Caribe? A festa, o cruzamento das fronteiras corporais e sensuais, vitais e espirituais podem deixar transparecer que não há espaço para os acontecimentos cotidianos da miséria, do desemprego, da violência e da indiferença. Não é assim. [...]. A vida se vive plenamente, tanto nos momentos de dor quanto nos momentos de festa. E no meio dos sofrimentos que se afirma a vida em sua plenitude, e é festejando que se afirma a esperança naqueles tempos em que as lágrimas deixarão de derramar-se. Neste tempo presente, o da festa, nós podemos olhar para trás, resgatar a memória, recuperando as experiências de resgate da vida, de libertação é a anamesis. Também caminhamos para frente com a nossa memória e nos alegramos antecipadamente com a vida eterna que um dia virá: é a prolepsis (TAMEZ, 2007, p. 147).

A festividade e o lúdico estão associados à contemplação e à qualificação da beleza da criação, sem que "beleza” seja compreendida dentro de padrões hegemônicos e estereotipados e nem de normatizações ideológicas. O teólogo Keith Ward, ao estabelecer um tipo de plataforma de comunicação da fé para a realidade cultural moderna, mostra que

o autêntico sentido religioso consiste em discernir o infinito e a eternidade no âmbito do limitado e do provisório, ver em todas as formas particulares de beleza uma Beleza de perfeição ilimitada e valor eterno. $O$ sentido de uma presença fundida, que vive na luz e no ar e no céu e na mente humana: o sentido de tal presença, que se divide, como a luz, em milhares de raios brilhantes de individualidade, cada um assumindo o caráter de seu próprio ambiente: o sentido de um mundo preenchido com presenças sublimes e fundidas, múltiplas e, ainda assim, unas, belas e difíceis, cor de vinho tinto e dedos rosados: este é o sentido dos deuses, que excitam a reverência humana e assustam, atemorizam e encantam (WARD, 2009, p. 31) .

As festas, a ruptura irônica e criativa com os padrões sociais, as celebrações, o prazer, as devoções, o cotidiano — sofrido e alegre — revelam o papel da dimensão lúdica na existência humana. Deste conjunto de experiências, fronteiriço às práticas políticas e de conscientização social, surgem visões de reforço e de recriação de identidades, socialização e um refazer da vida com novas utopias e dignidade, nas trilhas da justiça, da paz e da integridade da criação.

\section{Referências}

AGAMBEN, G. Infância e história: destruição da experiência e origem da história. Belo Horizonte: Editora UFMG, 2005. 
AGAMBEN, G. Homo Sacer: O poder soberano e a vida nua. Belo Horizonte: Editora UFMG, 2010.

AGAMBEN, G. Homo Sacer IV, 2. O uso dos corpos. São Paulo: Boitempo, 2017.

ASSMANN, S. “Apresentação”. In: AGAMBEN, G. Profanações. São Paulo: Boitempo Editorial, 2007.

AQUINO JUNIOR, F. Teoria teológica \& Práxis teologal: sobre o método da Teologia da Libertação. São Paulo: Paulinas, 2012.

ARAGÃO, G. "Do transdisciplinar ao transreligioso" (p. 133-148). In: TEPEDINO, A. M. \& ROCHA, A. A teia do conhecimento: fé, ciência e transdisciplinaridade. São Paulo: Paulinas, 2008.

ALVES, R. O enigma da religião. Petrópolis: Vozes, 1975.

ALVES, R. Dogmatismo e tolerância. São Paulo: Paulinas, 1982a.

ALVES, R. Variações sobre a vida e a morte: a teologia e sua fala. São Paulo: Paulinas, $1982 b$. ALVES, R. Creio na ressurreição do corpo: meditações. Rio de Janeiro: CEDI, 1982C.

ALVES, R. A gestação do futuro. São Paulo: Papirus, 1986.

ALVES, R. Lições sobre feitiçaria: meditações sobre a poesia. São Paulo: Loyola, 2001. ALVES, R. O Deus que conheço. São Paulo: Verus Editora, 2010.

BHABHA, H. K. O Local da Cultura. Belo Horizonte: Editora UFMG, 2001.

BINGEMER, M. C. Teologia Latino-Americana: raízes e ramos. Petrópolis: Vozes, 2017.

CATENACI, G. "Rubem Alves: um contemporâneo" (p. 101-123). In: RIBEIRO, C. O. (org.). Teologia Protestante Latino-Americana: um debate ecumênico. São Paulo: Terceira Via, 2018.

CAMPOS, B. M.; MARIANI, C. B.; RIBEIRO, C. O. (orgs.). Rubem Alves e as contas de vidro. São Paulo: Loyola, 2020.

COX, H. A Festa dos Foliões: um ensaio teológico sobre festividade e fantasia. Petrópolis: Vozes, 1974.

GT “Espiritualidades contemporâneas, pluralidade religiosa e diálogo". Disponível em: http://www.unicap.br/observatorio2/?p=2586. Acesso em: 14 maio 2019.

IDÍGORAS, J. L. Vocabulário Teológico para a América Latina. São Paulo: Paulinas, 1983.

LUCKNER, R. C. S.; KELM, T. R. E.; RIBEIRO, C. O. "Dos jardins com Heidegger à profanação da política: itinerário de Giorgio Agamben” (p. 9-54). In: RIBEIRO, C. O. (org.). Giorgio Agamben em foco. Curitiba: Prismas, 2017. 
NOGUEIRA, P. A. S. (org.). "A poética da religião em Rubem Alves" [dossiê]. Estudos de Religião, v. 31, n. 2, p. 153-316, maio/ago. 2017.

MIGNOLO, W. Delinking. The rethoric of modernity, the logic of coloniality and the grammar of de-coloniality. Cultural studies, Abingdon-on-Thames, Routledge, v. 2 and 3, n. 21, p. 449-514, Mar./May 2007.

MIGNOLO, W. Desobediência epistêmica: a opção descolonial e o significado de identidade em política. Cadernos de Letras da UFF, Niterói, n. 34, p. 287-324, 2008.

MORIN, E. Educação Ambiental na Escola, História e Contexto. In: MILANEZ, F. (Org.). Educação Ambiental. São Paulo: Paulus, 2008. 36 min., Digital.

MORIN, E. ; MOIGNE, J-L. A inteligência da complexidade. São Paulo: Peirópolis, 2000.

RIBEIRO, C. O. Testemunho e Libertação: a Teologia Latino-Americana em Questão. São Paulo: Fonte Editorial, 2016.

RIBEIRO, C. O. "O princípio pluralista: bases teóricas, conceituais e possibilidades de aplicação”. Revista de Cultura Teológica, v. 25, p. 234-254, $2017 a$.

RIBEIRO, C. O. “O princípio pluralista”. Cadernos de Teologia Pública - IHU, v. 14, n. 128, 2017b.

RIBEIRO, C. O. "A dimensão política da Teologia Protestante da Libertação. Revista Brasileira de História das Religiões, v. 11, n. 32, p. 75-102, 2018.

RIBEIRO, C. O. "A fé para além da religião, a gratuidade para além da política: Rubem Alves em jogo". Numen, v. 22, n. 2, p. 95-106, 2019.

RIBEIRO, C. O. “O debate sobre o princípio pluralista”. Cadernos de Teologia Pública IHU, v. 17, n. 145, 2020.

SANTOS, B. S. A gramática do tempo: para uma nova cultura política. São Paulo: Cortez, 2010.

TAMEZ, E. "Teologia e festa” (p. 141-149). In: ALMEIDA, E. F.; LONGUINI NETO, L. Teologia para quê? Rio de Janeiro: Mauad X, 2007.

WARD, K. Deus: um guia para os perplexos. Rio de Janeiro-RJ, DIFEL, 2009. 